\section{Kidney \\ Blood Pressure Research}

Original Paper

\title{
Down-Regulation of Renal Klotho Expression by Shiga Toxin 2
}

\author{
Martina Feger ${ }^{\mathrm{a}}$ Sobuj Mia ${ }^{\mathrm{a}}$ Tatsiana Pakladok ${ }^{\mathrm{a}} \quad$ Jan P. Nicolay $^{\mathrm{b}, \mathrm{c}}$ Ioana Alesutan ${ }^{\mathrm{a}}$ \\ Stefan W. Schneider ${ }^{\text {b Jakob Voelkl }}{ }^{\text {F }}$ Florian Lang ${ }^{\text {a }}$
}

aDepartment of Physiology, University of Tübingen, Tübingen; ${ }^{b}$ Department of Dermatology, University Medical Center Mannheim, Ruprecht-Karls-University of Heidelberg, Mannheim; 'Department of Immunogenetics, German Cancer Research Center, Heidelberg, Germany

\section{Ke Words}

25-hydroxyvitamin $D_{3}$ 1- $\alpha$-hydroxylase $\cdot 1,25(\mathrm{OH})_{2} D_{3} \cdot$ klotho $\cdot$ FGF23 $\cdot$ phosphate $\cdot$ p38 MAPK

\begin{abstract}
Background/Aims: Shiga toxin 2 may trigger classical hemolytic uremic syndrome (HUS) eventually leading to renal failure. Klotho, a transmembrane protein, protease and hormone mainly expressed in kidney is involved in the regulation of renal phosphate excretion and also retains renal protective effects. Renal failure is associated with renal depletion of klotho. The present study explored the influence of Shiga toxin 2 on renal klotho expression. Methods: Mice were injected with either solvent or Shiga toxin 2 and urinary flow rate and phosphate excretion were determined in metabolic cages. Renal transcript levels were measured by quantitative RT-PCR and renal protein abundance by Western blotting. Plasma concentrations of $1,25(\mathrm{OH})_{2} \mathrm{D}_{3}$ and FGF23 were determined by ELISA and plasma phosphate and urea concentrations by photometry. Results: Shiga toxin 2 treatment was followed by increase of plasma urea concentration, urinary flow rate and renal phosphate excretion but not of plasma phosphate concentration. Shiga toxin 2 treatment strongly decreased klotho mRNA expression and klotho protein abundance in renal tissue. Shiga toxin 2 treatment further increased tumor necrosis factor $(\operatorname{Tnf} \alpha)$ mRNA levels, as well as protein abundance of phosphorylated p38 MAPK in renal tissue. The treatment significantly increased renal Cyp27b1 and decreased renal Cyp24a1 mRNA levels without significantly altering plasma $1,25(\mathrm{OH})_{2} \mathrm{D}_{3}$ levels. Shiga toxin 2 treatment was further followed by increase of plasma FGF23 concentrations. Conclusion: Shiga toxin 2 treatment stimulated Tnfo transcription, down-regulated renal klotho expression and increased FGF23 formation, effects presumably contributing to renal tissue injury.
\end{abstract}

M. Feger and S. Mia contributed equally and thus share first authorship

Prof. Dr. Florian Lang
Physiologisches Institut, Universität Tübingen, Gmelinstr. 5, D-72076 Tübingen (Germany) Tel. +49 707129 72194, Fax +49 7071295618

E-Mail florian.lang@uni-tuebingen.de 


\section{Kidney Blood Pressure Research}

Kidney Blood Press Res 2014;39:441-449

\begin{tabular}{l|l}
\hline DOI: 10.1159/000368457 & (C) 2014 S. Karger AG, Basel
\end{tabular}

Published onIIne: November 19, 2014

www.karger.com/kbr

\section{Introduction}

Infections with Shiga toxin producing Escherichia coli may lead to haemolytic uremic syndrome (HUS) [1-4], a disorder characterized by haemolytic anaemia with fragmented erythrocytes, thrombocytopenia and acute renal failure [2, 5-10]. Escherichia coli may produce Shiga toxins 1 and/or 2 (Vero toxins or Vero cytotoxins) [2, 11]. Mechanisms involved in triggering of acute renal injury following Shiga toxin exposure include damaging vascular endothelial cells, triggering cytokine secretion and/or complement activation [1]. Shiga toxin induced renal damage involves acute tubular damage [12].

Acute renal injury may be paralleled and fostered by decreased formation of klotho [13], a transmembrane protein mainly expressed in the kidney [14-17]. Klotho is secreted into blood, urine and spinal fluid $[18,19]$. Klotho serves a wide variety of functions including regulation of phosphate homeostasis $[17,20]$. Reductions of klotho are discussed as a sensitive biomarker of renal disease [13].

Klotho deficiency results in hyperphosphatemia with severe calcifications and dramatically reduced lifespan in mice [21, 22]. Klotho is required for the inhibitory effect of FGF23 on 25-hydroxyvitamin $\mathrm{D}_{3}$ 1- $\alpha$-hydroxylase (encoded by the Cyp27b1 gene). Accordingly, klotho deficiency results in excessive formation of $1,25(\mathrm{OH})_{2} \mathrm{D}_{3}$, which stimulates intestinal phosphate and $\mathrm{Ca}^{2+}$ absorption. The resulting hyperphosphatemia is followed by calcium phosphate precipitations and vascular calcification [22-24]. 1,25(OH) $\mathrm{D}_{3}$ stimulates klotho expression thereby closing a negative feedback loop [16]. Klotho expression is down-regulated by several inflammatory mediators and by aldosterone [25-27]. It is up-regulated by angiotensin II blockade [28]. Klotho is down-regulated by mineralocorticoid receptor activation and ADH [26] and is up-regulated by the moderately selective mineralocorticoid receptor antagonist spironolactone [29].

Besides its role in phosphate homeostasis, klotho further regulates several ion channels, influences epithelial-to-mesenchymal transition and counteracts aging [17, 22, 30, 31]. Klotho further inhibits apoptosis [32]. Klotho confers some protection of the kidney [27, $33,34]$ and klotho deficiency may aggravate acute kidney damage [13]. Beyond that, klotho counteracts vascular calcification $[22,35,36]$ as well as pathological cardiac remodelling [37]. In chronic kidney disease, klotho deficiency accelerates the progression of renal disease and the appearance of extra-renal complications [13]. The decrease of klotho expression in renal injury leads to FGF23 resistance [19]. In chronic kidney disease the decrease of klotho expression contributes to the development of hyperphosphatemia despite reduced $1,25(\mathrm{OH})_{2} \mathrm{D}_{3}$ levels [17].

Due to the diverse functions of klotho, the present study explored whether Shiga toxin 2 influences klotho expression in renal tissue.

\section{Materials and Methods}

\section{Animal experiments}

All animal experiments were conducted according to the German law for the care and use of laboratory animals and were approved by local authorities. Experiments were performed in C57Bl6 mice under control diet and access to drinking water ad libitum. Where indicated, mice were treated with intraperitoneal injection of Shiga toxin $2(1 \mathrm{ng} / 20 \mathrm{~g}$ body weight) at days 0,3 , and 6 [38]. After 8 days of treatment, mice were sacrificed and kidney tissues were rapidly removed and immediately snap frozen.

To determine urinary flow rate, the mice were placed individually in metabolic cages (Tecniplast, Hohenpeissenberg, Germany) as described previously $[39,40]$. The urinary phosphate concentration was determined colorimetrically utilizing a commercial diagnostic kit (Roche Diagnostics, Mannheim, Germany). Plasma urea and phosphate concentrations were determined by a photometric method (FUJI FDC 3500i, Sysmex, Norsted, Germany). ELISA was utilized to determine the plasma concentration of $1,25(\mathrm{OH})_{2} \mathrm{D}_{3}($ IDS, Frankfurt/Main, Germany) and of FGF23 (Immutopics, San Clemente, USA). 


\section{Kidney Blood Pressure Research}

\section{Kidney Blood Press Res 2014;39:441-449}

\begin{tabular}{l|l}
\hline DOI: $10.1159 / 000368457$ & (c) 2014 S. Karger AG, Basel
\end{tabular}

Published onIIne: November 19, 2014

www.karger.com/kbr

Feger/Mia/Pakladok/Nicolay/Alesutan/Schneider/Voelkl/Lang: Shiga Toxin 2-Sensitive Klotho Expression

\title{
Quantitative RT-PCR
}

Total RNA was isolated from mouse kidney tissues by using Trifast Reagent (Peqlab Biotechnologie $\mathrm{GmbH}$, Germany) according to the manufacturer's instructions [41]. Reverse transcription of $2 \mu \mathrm{g}$ RNA was performed using oligo(dT) ${ }_{12-18}$ primers (Invitrogen, Life Technologies GmbH, Germany) and SuperScriptIII Reverse Transcriptase (Invitrogen, Life Technologies GmbH, Germany). Quantitative real-time PCR was performed with the iCycler $\mathrm{iQ}^{\mathrm{TM}}$ Real-Time PCR Detection System (Bio-Rad Laboratories GmbH, Germany) and $\mathrm{iQ}^{\mathrm{TM}}$ Sybr Green Supermix (Bio-Rad Laboratories, GmbH, Germany) according to the manufacturer's instructions. The following mouse primers were used (5'-3' orientation):

\author{
Cyp24a1 fw: GTGAAGCGTGCGCCAAAAG; \\ Cyp24a1 rev: CTCACCGTCGGTCATCAGC; \\ Cyp27b1 fw: CAGTTTACGTTGCCGACCCTA; \\ Cyp27b1 rev: GGACAGTGACTTTCTTGTCGC; \\ Gapdh fw: AGGTCGGTGTGAACGGATTTG; \\ Gapdh rev: TGTAGACCATGTAGTTGAGGTCA; \\ Klotho fw: CCCTGTGACTTTGCTTGGG; \\ Klotho rev: CCCACAGATAGACATTCGGGT; \\ Tnf $\alpha$ fw: CTGAACTTCGGGGTGATCGG; \\ Tnf $\alpha$ rev: GGCTTGTCACTCGAATTTTGAGA.
}

The specificity of the PCR products was confirmed by analysis of the melting curves. All PCRs were performed in duplicate, and mRNA fold changes were calculated by the $2^{-\Delta \Delta \mathrm{Ct}}$ method using Gapdh as internal reference.

\section{Western blot analysis}

Renal tissue was lysed with ice-cold lysis buffer (Thermo Fisher Scientific, Rockford, IL, USA) supplemented with complete protease and phosphatase inhibitor cocktail (Thermo Fisher Scientific, Rockford, IL, USA). After centrifugation at $10000 \mathrm{rpm}$ for $5 \mathrm{~min}$, protein concentration was determined by Bradford assay (Biorad Laboratories, Hercules, CA, USA). Proteins were boiled in Roti Load 1 protein loading buffer (Carl Roth, Karlsruhe, Germany) at $100^{\circ} \mathrm{C}$ for $5 \mathrm{~min}$, separated on SDS-polyacrylamide gels and transferred to PVDF membranes. The membranes were incubated overnight at $4^{\circ} \mathrm{C}$ with rabbit antiphospho p38 MAPK (Thr180/Tyr182), rabbit anti-p38 (dilution 1:1000, Cell Signaling, Danvers, MA, USA), rat anti- $\alpha$-klotho antibody (dilution 1:1000, kindly provided by Kyowa Hakko Kirin Co. Ltd, Japan) or rabbit anti-GAPDH antibody (dilution 1:1000; Cell Signaling, Danvers, MA, USA) and then with secondary antirabbit HRP-conjugated antibody (dilution 1:1000; Cell Signaling, Danvers, MA) or secondary anti-rat HRPconjugated antibody (dilution 1:1000; Cell Signaling, Danvers, MA) for 1 hour at RT. For loading controls, the membranes were stripped in stripping buffer (Carl Roth, Karlsruhe, Germany) at $60^{\circ} \mathrm{C}$ for 5 min. Antibody binding was detected with the ECL Western Blotting Substrate (Pierce, Rockford, IL, USA). Bands were quantified using Quantity One Software (Bio-Rad, München, Germany) and results are shown as the ratio of total protein to GAPDH normalized to the control treated group.

\section{Statistics}

Data are provided as means \pm SEM, $n$ represents the number of independent experiments. All data were tested for significance using unpaired Student $t$-test (normally distributed data) or Mann-Whitney test (non-normally distributed data) according to Shapiro-Wilk test. Only results with $p<0.05$ were considered statistically significant.

\section{Results}

The present study explored the renal effects of Shiga toxin 2, which is involved in the development of haemolytic uremic syndrome, leading to renal injury. Shiga toxin 2 was injected (1ng/20g body weight) at days 0,3 , and 6 . After 8 days of treatment, Shiga toxin 2 


\section{Kidney \\ Blood Pressure Research}

Fig. 1. Effect of Shiga toxin 2 injection on plasma urea levels, urinary flow rate, urinary phosphate excretion and plasma phosphate concentration. Arithmetic means \pm SEM ( $n=4-5$ mice/group) of blood urea nitrogen (A, BUN, mg/ $\mathrm{dl})$, urinary flow rate $(\mathrm{B}, \mu \mathrm{l} / 24 \mathrm{~h} / \mathrm{g}$ BW), urinary phosphate excretion (C, $\mu \mathrm{mol} / 24 \mathrm{~h} / \mathrm{g} \mathrm{BW}$ ) and plasma phosphate concentration (D, mg/ dl) in mice after treatment with vehicle (Ctr, white bars) or with Shiga toxin 2 (HUS, black bars). $*(\mathrm{p}<0.05), \quad * *(\mathrm{p}<0.01) \quad$ indicate statistically significant differences from control treated mice.

\section{Kidney Blood Press Res 2014;39:441-449} \begin{tabular}{l|l}
\hline DOI: $10.1159 / 000368457$ & C 2014 S. Karger AG, Basel \\
Published onlIne: November 19, 2014 & www.karger.com/kbr
\end{tabular}

Published onIIne: November 19, 2014 Klotho Expression

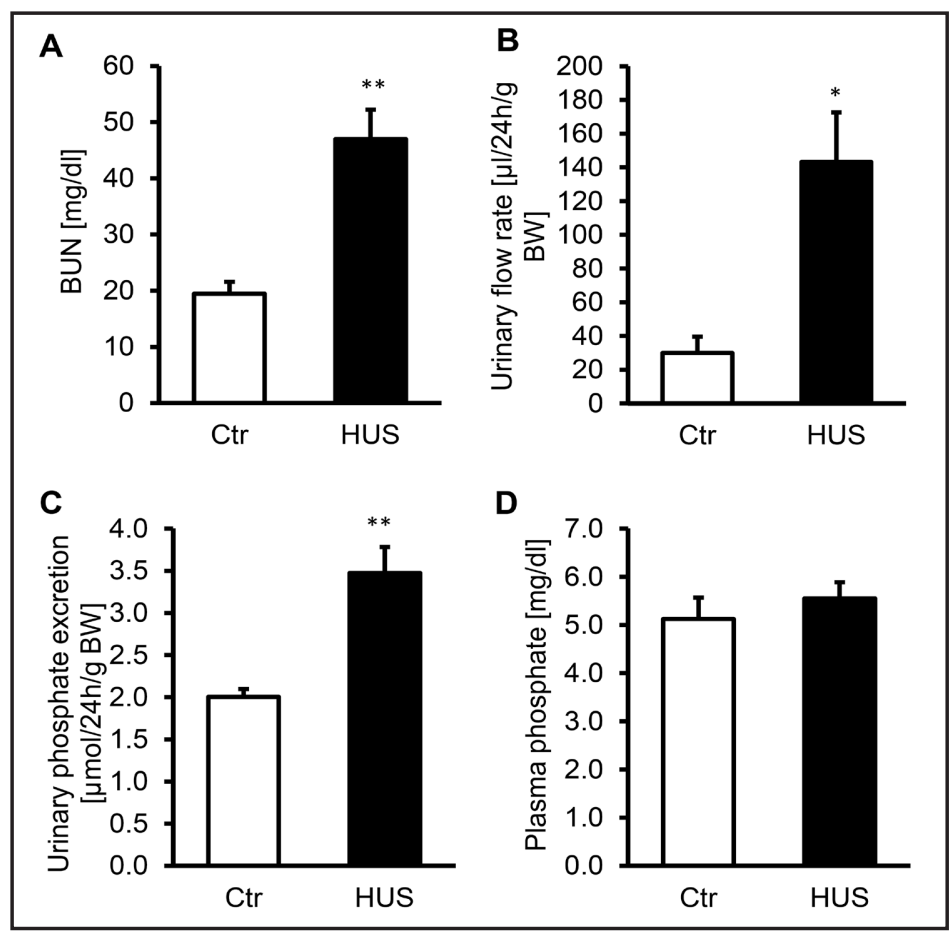

Fig. 2. Effect of Shiga toxin 2 injection on renal klotho transcript and protein levels. A. Arithmetic means \pm SEM $(n=5$, arbitrary units) of relative klotho mRNA expression in renal tissues from mice treated with vehicle (Ctr, white bar) or with Shiga toxin 2 (HUS, black bar). B. Representative original western blots and arithmetic means \pm SEM $(n=5$, arbitrary units) of klotho to Gap$\mathrm{dh}$ protein ratio in renal tissue from mice treated with vehicle (Ctr, white bar) or with Shiga toxin 2 (HUS, black bar). ${ }^{*}(\mathrm{p}<0.05)$, $* * *(p<0.001)$ indicate statistically significant differences from control treated mice.

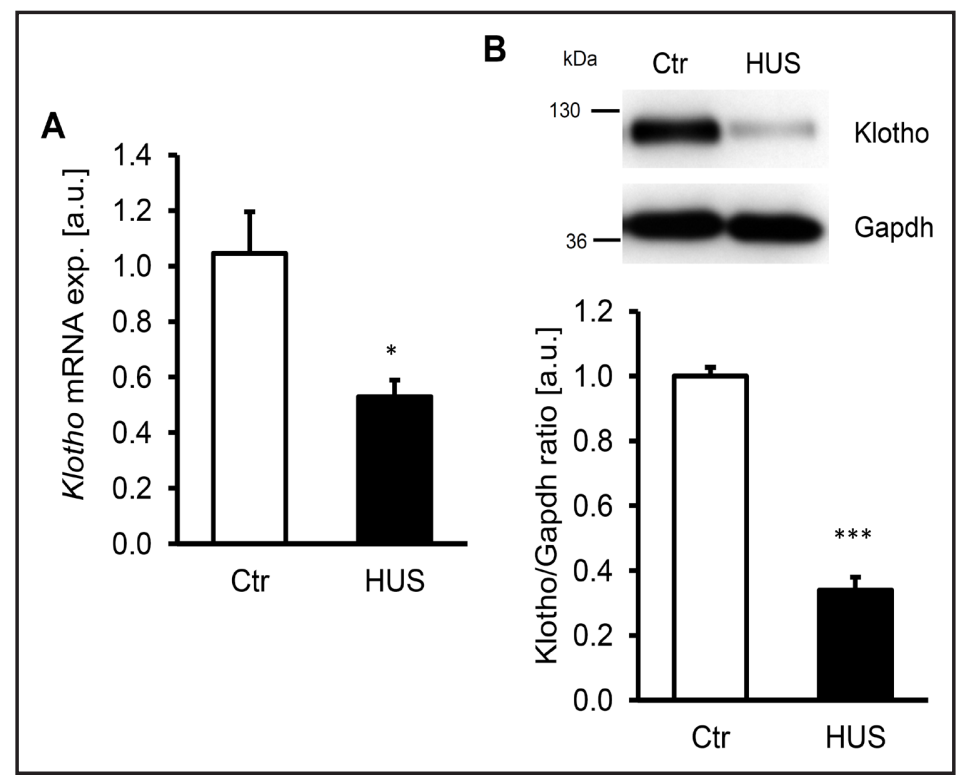

induced a substantial increase of blood urea nitrogen (BUN, Fig. 1A). Furthermore, Shiga toxin 2 treatment caused a significant increase of urinary flow rate (Fig. 1B). This was associated with an increased renal phosphate excretion (Fig. 1C). The plasma phosphate levels were not significantly modified by the treatment with Shiga toxin 2 (Fig. 1D).

After sacrificing the mice, kidneys were removed and transcript levels were quantified by RT-PCR, as well as protein abundance determined by Western blotting. As illustrated in Fig. 2A, Shiga toxin 2 injection significantly decreased the renal klotho mRNA levels. In accordance, the renal protein abundance of klotho was strongly reduced by Shiga toxin 2 treatments (Fig. 2B). 


\section{Kidney Blood Pressure Research}

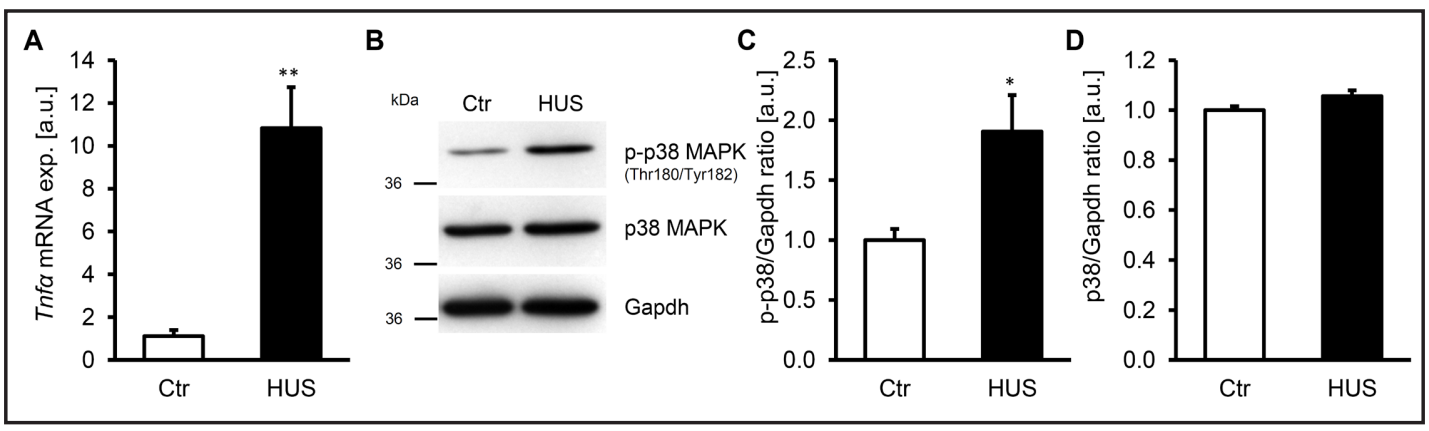

Fig. 3. Effect of Shiga toxin 2 injection on renal Tnf $\alpha$ expression and phospho-p38 MAPK and total p38 MAPK protein abundance. A. Arithmetic means \pm SEM ( $n=5$, arbitrary units) of relative Tnf $\alpha$ mRNA expression in renal tissues from mice treated with vehicle (Ctr, white bar) or with Shiga toxin 2 (HUS, black bar). B. Representative original western blots showing phosphorylated p38 MAPK, total p38 MAPK and Gapdh protein abundance in renal tissues from mice treated with vehicle (Ctr) or with Shiga toxin 2 (HUS). Arithmetic means \pm SEM ( $n=5$, arbitrary units) of normalized phosphorylated p38 MAPK to Gapdh protein ratio (C) and p38 MAPK to Gapdh protein ratio (D) in renal tissues from mice treated with vehicle (Ctr, white bars) or with Shiga toxin 2 (HUS, black bars). ${ }^{*}(\mathrm{p}<0.05),{ }^{* *}(\mathrm{p}<0.01)$ indicate statistically significant differences from control treated mice.

To investigate a possible underlying cause for the reduction in klotho expression, the renal expression of Tnfo was determined. As a result, Shiga toxin 2 injection strongly increased the transcript levels of Tnfo in kidney tissues (Fig. 3A). Shiga toxin 2 injection was further followed by an increase of p38 MAPK phosphorylation in renal tissue. The total p38 MAPK protein abundance was not significantly modified by Shiga toxin 2 in the murine kidneys (Fig. 3B-D).

To investigate, whether the effects of Shiga toxin 2 on klotho expression affected the vitamin $\mathrm{D}_{3}$ metabolism, the transcript levels of 25-hydroxyvitamin $\mathrm{D}_{3} 1$ - $\alpha$-hydroxylase (Cyp27b1) and of 24-hydroxyvitamin $\mathrm{D}_{3} 1$ - $\alpha$-hydroxylase (Cyp24a1) were determined. As a result, the effect of Shiga toxin 2 on klotho expression was paralleled by a significant increase of Cyp27b1 mRNA expression and a significant decrease of Cyp24a1 mRNA expression (Fig. $4 A, B)$. In addition, Shiga toxin 2 treatment led to an increase of plasma FGF23 concentrations (Fig. 4C). The plasma 1,25(OH $)_{2} \mathrm{D}_{3}$ concentration tended to increase slightly, an effect, however, not reaching statistical significance (Fig. 4D).

\section{Discussion}

The present study reveals novel effects of Shiga toxin 2 from Escherichia coli, a causative agent of haemolytic uremic syndrome (HUS) [1-4]. Shiga toxin 2 treatment caused a marked reduction in renal klotho expression and increased plasma FGF23 levels. Injection of Shiga toxin 2 was followed by increase of plasma urea concentration and polyuria. Shiga toxin has previously been shown to interfere with urinary concentration [42].

The shiga toxin 2 treatment was paralleled by increase of renal Tnfo mRNA expression. Increased Tnfo signaling following Shiga toxin 2 treatment presumably contributes to the observed decrease of klotho expression, which was shown to be down-regulated by Tnf $\alpha$ [25]. Tnfo further downregulates klotho in endothelial cells [43]. Klotho deficiency is associated with increased p38 MAPK activity, which is in turn associated with down-regulation of klotho $[44,45]$. The p38 MAPK kinase is causally involved in the effects of Shiga toxin 2 and promotes Tnfo expression [46-49]. Along those lines the Shiga toxin-induced increase of Tnfo in renal tubular epithelial cells can be attenuated by a p38 inhibitor [50]. 


\section{Kidney \\ Blood Pressure Research}

Fig. 4. Effects of Shiga toxin 2 injection on renal Cyp27b1 and Cyp24a1 expression and plasma $1,25(\mathrm{OH})_{2} \mathrm{D}_{3}$ and FGF23 concentrations. Arithmetic means \pm SEM ( $n=5$, arbitrary units) of relative mRNA expression of Cyp27b1 (A) and Cyp24a1 (B) in renal tissues from mice treated for 8 days with vehicle (Ctr, white bars) or with Shiga toxin 2 (HUS, black bars). Arithmetic means \pm SEM ( $n=5$ mice/group) of plasma FGF23 (C, pg/ml) and $1,25(\mathrm{OH})_{2} \mathrm{D}_{3}(\mathrm{D}, \mathrm{pmol} / \mathrm{l})$ concentrations in mice after treatment with vehicle (Ctr, white bars) or with Shiga toxin 2 (HUS, black bars $) *^{*}(\mathrm{p}<0.05),{ }^{* *}(\mathrm{p}<0.01)$ indicate statistically significant differences from control treated mice.

\section{Kidney Blood Press Res 2014;39:441-449}

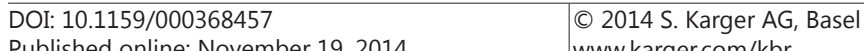

Publisned onIIne: November 19, 2014 www.karger.com/kbr

Klotho Expression

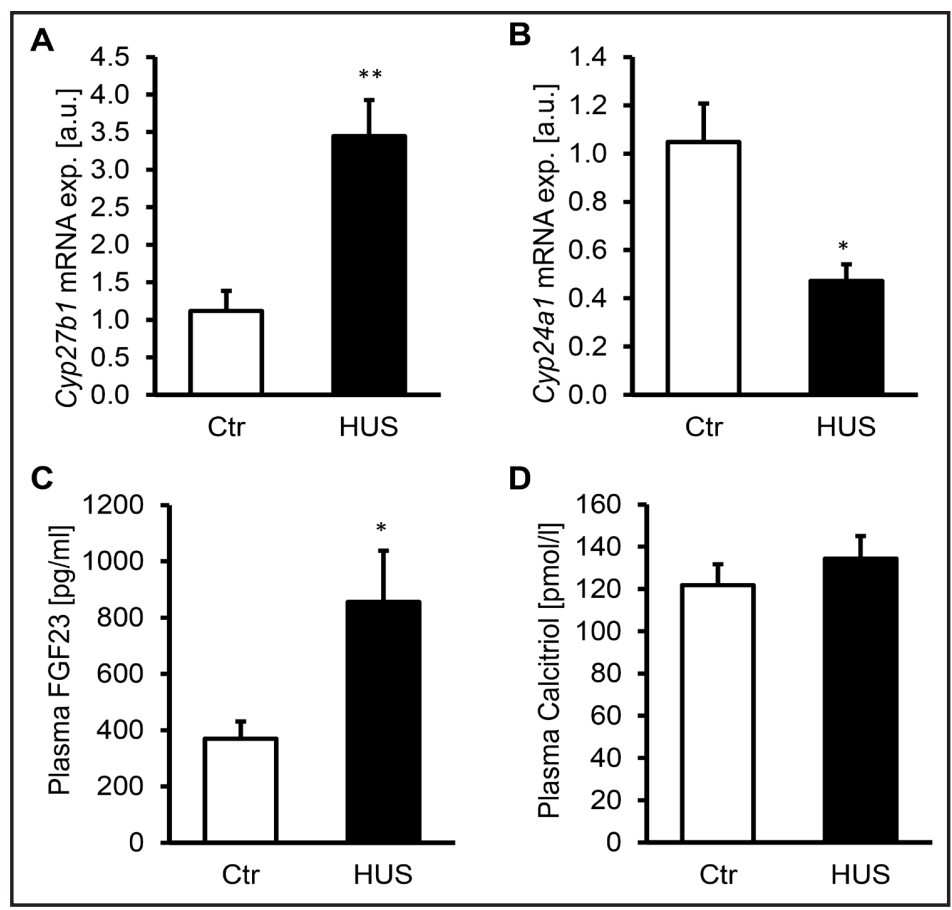

The effect of Shiga toxin 2 treatment on klotho mRNA levels and klotho protein abundance presumably accounts for the increase of renal Cyp27b1 and decrease of renal Cyp24a1 transcript levels. The decline of klotho expression compromises FGF23 signaling down-regulating Cyp27b1 and up-regulating Cyp24a1 expression [16, 51, 52]. The alterations of Cyp27b1 and Cyp24a1 transcript levels are thus presumably, at least in part, secondary to decreased klotho expression. Stimulation of Cyp27b1 enhances the formation of $1,25(\mathrm{OH})_{2} \mathrm{D}_{3}$ and inhibition of Cyp24a1 disrupts $1,25(\mathrm{OH})_{2} \mathrm{D}_{3}$ degradation. Nonetheless, no significant effects on plasma $1,25(\mathrm{OH})_{2} \mathrm{D}_{3}$ were observed. FGF23 release could be a compensatory mechanism for the polyuria [53]. The increased urinary phosphate excretion could, at least partially, result from increased FGF23 release. The present observations do, however, not rule out more direct effects of Shiga toxin 2 on klotho, Cyp27b1 and Cyp24a1 expression and/ or FGF23 release.

The klotho depleting effect of Shiga toxin 2 could contribute to the pathophysiology of HUS. Klotho is a biomarker of renal function, and could also serve to detect and quantify the renal effects of haemolytic uremic syndrome [19]. Besides its role as a biomarker, klotho depletion may be causally linked to renal damage. The down-regulation of klotho may sensitize the kidneys to injury [13]. Klotho deficiency has previously been shown to accelerate the progression of renal disease and the appearance of extra-renal complications, especially in the vasculature [13]. Moreover, klotho counteracts vascular dysfunction, renal fibrosis and aging [31, 35, 54-56].

\section{Conclusion}

Shiga toxin 2 treatment stimulates renal Tnfo expression, up-regulates plasma FGF23 concentrations and down-regulates renal klotho expression. 


\section{Kidney \\ Bloód Pressure Research}

\section{Disclosure Statement}

Feger/Mia/Pakladok/Nicolay/Alesutan/Schneider/Voelkl/Lang: Shiga Toxin 2-Sensitive Klotho Expression

All authors disclose that they have no potential conflict of interest and the results presented in this paper have not been published previously in whole or part, except in abstract format.

\section{Acknowledgements}

The authors acknowledge the technical assistance of E. Faber and the meticulous preparation of the manuscript by Tanja Loch and Sari Rübe. The klotho antibody was a kind gift from Kyowa Hakko Kirin Co.Ltd, Japan. This study was supported by the Deutsche Forschungsgemeinschaft, the Helmholtz Association and the Open Access Publishing Fund of Tuebingen University.

\section{References}

1 Hauswaldt S, Nitschke M, Sayk F, Solbach W, Knobloch JK: Lessons Learned From Outbreaks of Shiga Toxin Producing Escherichia coli. Curr Infect Dis Rep 2013;15:4-9.

2 Karmali MA, Petric M, Lim C, Fleming PC, Steele BT: Escherichia coli cytotoxin, haemolytic-uraemic syndrome, and haemorrhagic colitis. Lancet 1983;2:1299-1300.

-3 Karmali MA, Steele BT, Petric M, Lim C: Sporadic cases of haemolytic-uraemic syndrome associated with faecal cytotoxin and cytotoxin-producing Escherichia coli in stools. Lancet 1983;1:619-620.

-4 Tarr PI, Gordon CA, Chandler WL: Shiga-toxin-producing Escherichia coli and haemolytic uraemic syndrome. Lancet 2005;365:1073-1086.

5 Moake JL: Thrombotic thrombocytopenic purpura and the hemolytic uremic syndrome. Arch Pathol Lab Med 2002;126:1430-1433.

6 Corrigan JJ, Jr., Boineau FG: Hemolytic-uremic syndrome. Pediatr Rev 2001;22:365-369.

7 Bitzan M, Bickford BB, Foster GH: Verotoxin (shiga toxin) sensitizes renal epithelial cells to increased heme toxicity: possible implications for the hemolytic uremic syndrome. J Am Soc Nephrol 2004;15:2334-2343.

8 Boyce TG, Swerdlow DL, Griffin PM: Escherichia coli 0157:H7 and the hemolytic-uremic syndrome. N Engl J Med 1995;333:364-368.

-9 Hughes AK, Ergonul Z, Stricklett PK, Kohan DE: Molecular basis for high renal cell sensitivity to the cytotoxic effects of shigatoxin-1: upregulation of globotriaosylceramide expression. J Am Soc Nephrol 2002;13:22392245.

10 Te Loo DM, van Hinsbergh VW, van den Heuvel LP, Monnens LA: Detection of verocytotoxin bound to circulating polymorphonuclear leukocytes of patients with hemolytic uremic syndrome. J Am Soc Nephrol 2001;12:800-806.

11 Kaper JB, Nataro JP, Mobley HL: Pathogenic Escherichia coli. Nat Rev Microbiol 2004;2:123-140.

-12 Porubsky S, Federico G, Muthing J, Jennemann R, Gretz N, Buttner S, Obermuller N, Jung O, Hauser IA, Grone E, Geiger H, Grone HJ, Betz C: Direct acute tubular damage contributes to Shigatoxin-mediated kidney failure. J Pathol 2014;234:120-133.

13 Hu MC, Kuro-o M, Moe OW: The emerging role of Klotho in clinical nephrology. Nephrol Dial Transplant 2012;27:2650-2657.

14 Drueke TB: Klotho, FGF23, and FGF receptors in chronic kidney disease: a yin-yang situation? Kidney Int 2010;78:1057-1060.

15 Takeshita K, Fujimori T, Kurotaki Y, Honjo H, Tsujikawa H, Yasui K, Lee JK, Kamiya K, Kitaichi K, Yamamoto K, Ito M, Kondo T, Iino S, Inden Y, Hirai M, Murohara T, Kodama I, Nabeshima Y: Sinoatrial node dysfunction and early unexpected death of mice with a defect of klotho gene expression. Circulation 2004;109:1776-1782.

16 Tsujikawa H, Kurotaki Y, Fujimori T, Fukuda K, Nabeshima Y: Klotho, a gene related to a syndrome resembling human premature aging, functions in a negative regulatory circuit of vitamin D endocrine system. Mol Endocrinol 2003;17:2393-2403. 


\section{Kidney \\ Blood Pressure Research}

Kidney Blood Press Res 2014;39:441-449

\begin{tabular}{l|l}
\hline DOI: 10.1159/000368457 & (C) 2014 S. Karger AG, Basel
\end{tabular}

Publisnea onine: November 19, 2014

www.karger.com/kbr

17 Kuro-o M: Klotho in health and disease. Curr Opin Nephrol Hypertens 2012;21:362-368.

18 Imura A, Iwano A, Tohyama O, Tsuji Y, Nozaki K, Hashimoto N, Fujimori T, Nabeshima Y: Secreted Klotho protein in sera and CSF: implication for post-translational cleavage in release of Klotho protein from cell membrane. FEBS Lett 2004;565:143-147.

19 Akimoto T, Yoshizawa H, Watanabe Y, Numata A, Yamazaki T, Takeshima E, Iwazu K, Komada T, Otani N, Morishita Y, Ito C, Shiizaki K, Ando Y, Muto S, Kuro O, Kusano E: Characteristics of urinary and serum soluble Klotho protein in patients with different degrees of chronic kidney disease. BMC Nephrol 2012;13:155.

20 Dermaku-Sopjani M, Sopjani M, Saxena A, Shojaiefard M, Bogatikov E, Alesutan I, Eichenmuller M, Lang F: Downregulation of NaPi-IIa and NaPi-IIb Na-coupled phosphate transporters by coexpression of Klotho. Cell Physiol Biochem 2011;28:251-258.

-21 Kuro-o M, Matsumura Y, Aizawa H, Kawaguchi H, Suga T, Utsugi T, Ohyama Y, Kurabayashi M, Kaname T, Kume E, Iwasaki H, Iida A, Shiraki-Iida T, Nishikawa S, Nagai R, Nabeshima YI: Mutation of the mouse klotho gene leads to a syndrome resembling ageing. Nature 1997;390:45-51.

22 Hu MC, Shi M, Zhang J, Quinones H, Griffith C, Kuro-o M, Moe OW: Klotho Deficiency Causes Vascular Calcification in Chronic Kidney Disease. J Am Soc Nephrol 2011;22:124-136.

23 Kuro-o M: Klotho. Pflugers Arch 2010;459:333-343.

24 Ohnishi M, Razzaque MS: Dietary and genetic evidence for phosphate toxicity accelerating mammalian aging. FASEB J 2010;24:3562-3571.

-25 Moreno JA, Izquierdo MC, Sanchez-Nino MD, Suarez-Alvarez B, Lopez-Larrea C, Jakubowski A, Blanco J, Ramirez R, Selgas R, Ruiz-Ortega M, Egido J, Ortiz A, Sanz AB: The inflammatory cytokines TWEAK and TNFalpha reduce renal klotho expression through NFkappaB. J Am Soc Nephrol 2011;22:1315-1325.

-26 Tang C, Pathare G, Michael D, Fajol A, Eichenmuller M, Lang F: Downregulation of Klotho expression by dehydration. Am J Physiol Renal Physiol 2011;301:F745-F750.

-27 Tang R, Zhou QL, Ao X, Peng WS, Veeraragoo P, Tang TF: Fosinopril and losartan regulate klotho gene and nicotinamide adenine dinucleotide phosphate oxidase expression in kidneys of spontaneously hypertensive rats. Kidney Blood Press Res 2011;34:350-357.

28 Yoon HE, Ghee JY, Piao S, Song JH, Han DH, Kim S, Ohashi N, Kobori H, M K-o, Yang CW: Angiotensin II blockade upregulates the expression of Klotho, the anti-ageing gene, in an experimental model of chronic cyclosporine nephropathy. Nephrol Dial Transplant 2011;26:800-813.

29 Alesutan I, Feger M, Pakladok T, Mia S, Ahmed MS, Voelkl J, Lang F: 25-hydroxyvitamin D3 1-alphahydroxylase-dependent stimulation of renal klotho expression by spironolactone. Kidney Blood Press Res 2013;37:475-487.

-30 Doi S, Zou Y, Togao O, Pastor JV, John GB, Wang L, Shiizaki K, Gotschall R, Schiavi S, Yorioka N, Takahashi M, Boothman DA, Kuro-o M: Klotho inhibits transforming growth factor-beta1 (TGF-beta1) signaling and suppresses renal fibrosis and cancer metastasis in mice. J Biol Chem 2011;286:8655-8665.

-31 Kurosu H, Yamamoto M, Clark JD, Pastor JV, Nandi A, Gurnani P, McGuinness OP, Chikuda H, Yamaguchi M, Kawaguchi H, Shimomura I, Takayama Y, Herz J, Kahn CR, Rosenblatt KP, Kuro-o M: Suppression of aging in mice by the hormone Klotho. Science 2005;309:1829-1833.

-32 Panesso MC, Shi M, Cho HJ, Paek J, Ye J, Moe OW, Hu MC: Klotho has dual protective effects on cisplatininduced acute kidney injury. Kidney Int 2014;85:855-870.

-33 Haruna Y, Kashihara N, Satoh M, Tomita N, Namikoshi T, Sasaki T, Fujimori T, Xie P, Kanwar YS: Amelioration of progressive renal injury by genetic manipulation of Klotho gene. Proc Natl Acad Sci USA 2007;104:23312336.

-34 Ko GJ, Lee EA, Jeon US, Pyo HJ, Chin HJ, Chae DW, Kim S, Kwon YJ: The Association of Klotho Polymorphism with Disease Progression and Mortality in IgA Nephropathy. Kidney Blood Press Res 2012;36:191-199.

-35 Lim K, Lu TS, Molostvov G, Lee C, Lam FT, Zehnder D, Hsiao LL: Vascular Klotho deficiency potentiates the development of human artery calcification and mediates resistance to fibroblast growth factor 23. Circulation 2012;125:2243-2255.

-36 Voelkl J, Alesutan I, Leibrock CB, Quintanilla-Martinez L, Kuhn V, Feger M, Mia S, Ahmed MS, Rosenblatt KP, Kuro-o M, Lang F: Spironolactone ameliorates PIT1-dependent vascular osteoinduction in klothohypomorphic mice. J Clin Invest 2013;123:812-822.

-37 Xie J, Cha SK, An SW, Kuro-o M, Birnbaumer L, Huang CL: Cardioprotection by Klotho through downregulation of TRPC6 channels in the mouse heart. Nat Commun 2012;3:1238. 


\section{Kidney \\ Blood Pressure Research}

Kidney Blood Press Res 2014;39:441-449

\begin{tabular}{l|l}
\hline DOI: $10.1159 / 000368457$ & (c) 2014 S. Karger AG, Basel
\end{tabular}

Published onIIne: November 19, 2014

www.karger.com/kbr Klotho Expression

-38 Sauter KA, Melton-Celsa AR, Larkin K, Troxell ML, O'Brien AD, Magun BE: Mouse model of hemolytic-uremic syndrome caused by endotoxin-free Shiga toxin 2 (Stx2) and protection from lethal outcome by anti-Stx2 antibody. Infect Immun 2008;76:4469-4478.

-39 Pathare G, Foller M, Michael D, Walker B, Hierlmeier M, Mannheim JG, Pichler BJ, Lang F: Enhanced FGF23 serum concentrations and phosphaturia in gene targeted mice expressing WNK-resistant SPAK. Kidney Blood Press Res 2012;36:355-364.

40 Pathare G, Foller M, Daryadel A, Mutig K, Bogatikov E, Fajol A, Almilaji A, Michael D, Stange G, Voelkl J, Wagner CA, Bachmann S, Lang F: OSR1-sensitive renal tubular phosphate reabsorption. Kidney Blood Press Res 2012;36:149-161.

-41 Feger M, Fajol A, Lebedeva A, Meissner A, Michael D, Voelkl J, Alesutan I, Schleicher E, Reichetzeder C, Hocher B, Qadri SM, Lang F: Effect of Carbon Monoxide Donor CORM-2 on Vitamin D3 Metabolism. Kidney Blood Press Res 2013;37:496-505.

42 Sugatani J, Komiyama N, Mochizuki T, Hoshino M, Miyamoto D, Igarashi T, Hoshi S, Miwa M: Urinary concentrating defect in rats given Shiga toxin: elevation in urinary AQP2 level associated with polyuria. Life Sci 2002;71:171-189.

43 Carracedo J, Buendia P, Merino A, Madueno JA, Peralbo E, Ortiz A, Martin-Malo A, Aljama P, Rodriguez M, Ramirez R: Klotho modulates the stress response in human senescent endothelial cells. Mech Ageing Dev 2012;133:647-654.

44 Hsieh CC, Kuro-o M, Rosenblatt KP, Brobey R, Papaconstantinou J: The ASK1-Signalosome regulates p38 MAPK activity in response to levels of endogenous oxidative stress in the Klotho mouse models of aging. Aging (Albany NY) 2010;2:597-611.

45 Zhou Q, Lin S, Tang R, Veeraragoo P, Peng W, Wu R: Role of Fosinopril and Valsartan on Klotho Gene Expression Induced by Angiotensin II in Rat Renal Tubular Epithelial Cells. Kidney Blood Press Res 2010;33:186-192.

-46 Fu XJ, Iijima K, Nozu K, Hamahira K, Tanaka R, Oda T, Yoshikawa N, Matsuo M: Role of p38 MAP kinase pathway in a toxin-induced model of hemolytic uremic syndrome. Pediatr Nephrol 2004;19:844-852.

-47 Ikeda M, Gunji Y, Yamasaki S, Takeda Y: Shiga toxin activates p38 MAP kinase through cellular $\mathrm{Ca}(2+)$ increase in Vero cells. FEBS Lett 2000;485:94-98.

48 Peng T, Lu X, Lei M, Moe GW, Feng Q: Inhibition of p38 MAPK decreases myocardial TNF-alpha expression and improves myocardial function and survival in endotoxemia. Cardiovasc Res 2003;59:893-900.

49 Ramesh G, Brian Reeves W: Cisplatin increases TNF-alpha mRNA stability in kidney proximal tubule cells. Ren Fail 2006;28:583-592.

50 Nakamura A, Johns EJ, Imaizumi A, Yanagawa Y, Kohsaka T: Activation of beta(2)-adrenoceptor prevents shiga toxin 2-induced TNF-alpha gene transcription. J Am Soc Nephrol 2001;12:2288-2299.

51 Yoshida T, Fujimori T, Nabeshima Y: Mediation of unusually high concentrations of 1,25-dihydroxyvitamin D in homozygous klotho mutant mice by increased expression of renal 1alpha-hydroxylase gene. Endocrinology 2002;143:683-689.

52 Razzaque MS, Sitara D, Taguchi T, St Arnaud R, Lanske B: Premature aging-like phenotype in fibroblast growth factor 23 null mice is a vitamin D-mediated process. FASEB J 2006;20:720-722.

-53 Andrukhova O, Slavic S, Smorodchenko A, Zeitz U, Shalhoub V, Lanske B, Pohl EE, Erben RG: FGF23 regulates renal sodium handling and blood pressure. EMBO Mol Med 2014;6:744-759.

-54 Ikushima M, Rakugi H, Ishikawa K, Maekawa Y, Yamamoto K, Ohta J, Chihara Y, Kida I, Ogihara T: Antiapoptotic and anti-senescence effects of Klotho on vascular endothelial cells. Biochem Biophys Res Commun 2006;339:827-832.

-55 Kusaba T, Okigaki M, Matui A, Murakami M, Ishikawa K, Kimura T, Sonomura K, Adachi Y, Shibuya M, Shirayama T, Tanda S, Hatta T, Sasaki S, Mori Y, Matsubara H: Klotho is associated with VEGF receptor-2 and the transient receptor potential canonical-1 Ca2+ channel to maintain endothelial integrity. Proc Natl Acad Sci USA 2010;107:19308-19313.

-56 Satoh M, Nagasu H, Morita Y, Yamaguchi TP, Kanwar YS, Kashihara N: Klotho protects against mouse renal fibrosis by inhibiting Wnt signaling. Am J Physiol Renal Physiol 2012;303:F1641-F1651. 